\title{
Effect of Guideline Education on Knowledge and Performance of Mothers regarding Using of Cook Salt for Management of Infants with Granuloma Umbilical
}

\section{Sabah Mohammed Sharshour ${ }^{1}$, Noha Mohammed Ashour Gebril ${ }^{2}$, Mabrouka Atia Nada ${ }^{3}$}

\author{
${ }^{1}$ Lecture of Pediatric Nursing, Faculty of Nursing, Tanta University, Egypt, \\ ${ }^{2}$ Lecture of Pediatric Medicine, Faculty of Medicine, Menoufia University, Egypt, \\ ${ }^{3}$ Colleage of Pediatric Nursing, Menoufia University Hospital, Egypt.
}

\begin{abstract}
Granuloma Umbilical from major problem in neonates and young infants. It is reported frequently by mothers as continuous leakage of secretion at umbilicus site following cord separation. Delayed management of granuloma, it remain oozing and causes persistent irritation for long period reach weeks. Several management modalities were performed for umbilical granuloma including; using cook salt, ligation of the granuloma, cauterization chemically with silver nitrate or copper sulphate, electro-cauterization, cryocauterization and excision surgical . Aim of the study: Evaluate mother knowledge and performance regarding using of cook salt for management of infants with granuloma umbilical. Subject and Methods: Research Design: A quasi-experimental research design was used Setting: The study was conducted at outpatient pediatric department of Tanta and Menoufia University Hospital. Tools: Two tools were used: Structure interview schedule was developed by the researcher included three parts: Tool I: Biosocial data of infants and their mother, mothers' knowledge and reported practice was evaluated by using observational check list about cook salt use for umbilical granuloma. Tool II: Guideline reported educational intervention for the mothers Results: Infants with granuloma showed complete resolution after course of cook salt treatment. Conclusion: Using of cook salt for management umbilical granuloma is costeffective, simple curative and safe mode of treatment which can be performed by mothers at home. Recommendation: Using of cook salt as a treatment modality should be more encouraged by the health staff.
\end{abstract}

Key words: knowledge, granuloma, cook salt. 


\section{Introduction}

Umbilical granuloma occur in about 1 in 500 babies. Regardless it generally harmless to the baby, it causes mothers a lot of anxiety, parents might worry regarding their infants developed an infection, pain at the umbilical and usually the appearance is worrisome. The cord normally dries out and gradually falls off at around 5-14 days following delivery. As the cord dried and falls off, the umbilicus base rapidly heals and covered with squamous epithelium. Delayed fall of the umbilical cord stump, leukocyte adhesion disorder should be suspected. The process of formation of granuloma totally unclear. Predisposing factors including; disrupted healing process and inflammation resulting in overgrowth of endothelial cells and inadequate epithelization. Also inflamed, often pinkish fleshy swelling with exudation may be formed ${ }^{(1.2) \text {. }}$

The first use of salt was in 1983, treating of over 100 infants with granuloma with no evidence of recurrence. Salt therapy has been shown to be safe and effective; it is popular with families and virtually free. Proper management of granuloma depends on corrective diagnosis confirmed by a competent professional then cook salt management can be carried out at home, with medical review only if symptoms do not resolve ${ }^{(3,4) \text {. }}$

Granuloma umbilical from major problem in neonates and young infants. It is acquired abnormalities, represents inflammation of granulated tissue that still not epithelialized. Over growth of granulated tissue can occur. Persistent of the granuloma for long time will need some type of therapy. Salt therapy usually clears the granuloma within days to weeks. If a complete cure is not occurred within this time; surgical intervention can be performed ${ }^{(5-8) \text {. }}$

Mechanism of cook salt work at granulated tissue; draws water out of the cells causing shirking granuloma; the skin around the umbilicus should be cleaned immediately with warm water then full dryness is obtained, soft paraffin jell to the surrounding skin, very small pinch of cook salt to the umbilical granuloma were applied, cover the affected area with a gauze swab for 30 minutes. After that time clean the affected area with warm water, remove all remaining particles of salt, then dry the area, and perform this technique twice a day for three days. After that time granuloma has become smaller, changed its color or completely dried up. A health professional should observe the granuloma after seven days (9-11). 


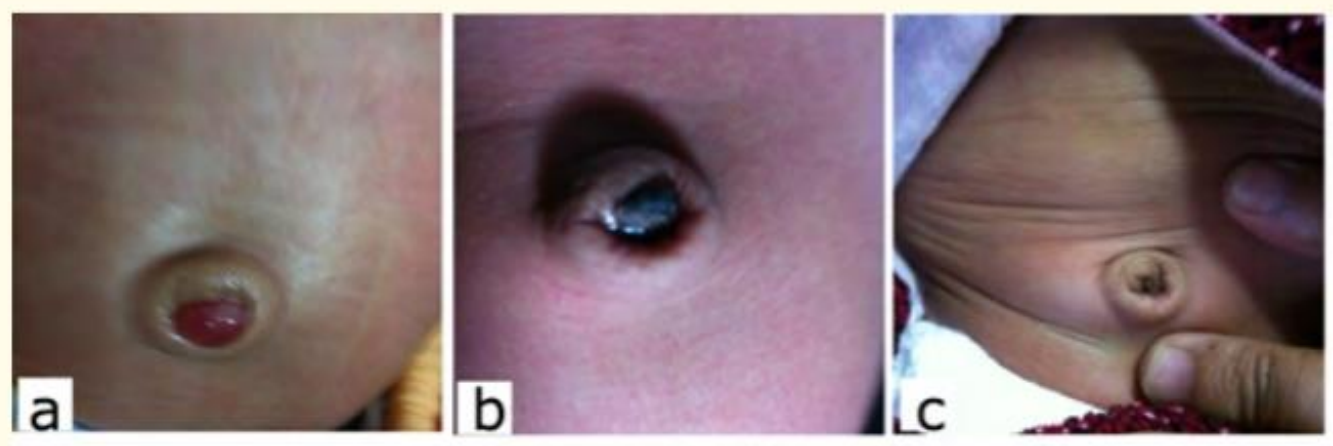

Figure 1: (a) Prior to treatment. (b) $2^{\text {nd }}$ day of salt therapy. (c) Post 3rd day of salt therapy.

Dhungel S.,et al. Outcomes and Cost Analysis of Salt Therapy Versus Silver Nitrate for Treatment Granuloma:4 Years' Experience in Private Health Center EC paediatrics 7.7(2018):653-9

\section{Aim of the study}

Was to assess Effect of guideline education on Knowledge and performance of mothers regarding using of cook salt for management of infants with granuloma umbilical.

\section{Research hypothesis}

Guideline education expected to improve Knowledge and performance of mothers regarding using of cook salt for management of infants with umbilical granuloma.

\section{Subjects and Method}

\section{Research Design:}

A quasi-experimental research design was used

\section{Setting:}

The study was conducted at outpatient pediatric department of Tanta and Menoufia University Hospital.

\section{Subjects:}

Convenience sample of 40 mothers attending to the clinics with their infants suffering from umbilical granuloma.

\section{Inclusion criteria}

Infant's ages ranged from three to 16 weeks and both sexes attending to the outpatient's clinics with umbilical granuloma.

\section{Exclusion criteria}

Umbilical discharge with no overgrowth, patent vitellio-intestinal duct (VID), umbilical sinus, patent urachus and omphalitis, infant received prior treatment before attending the clinic.

\section{Tools of data collection:}

Two tools were used to collect data.

Tool I: Structure interview schedule was developed by the researcher included three parts: Part (1): biosocial data of the infant such as: age, gender, birth order, type of delivery, feeding type, time of cord falling and response to management of granuloma. Part (2): biosocial data of the studied mothers such as age, education 
level, occupation and number of children.

Part (3): Mothers' knowledge about umbilical granuloma: it included fourteen questions related to mothers knowledge regarding definition of granuloma, time of development of granuloma after falling of umbilical stump, pain and irritation of the baby skin around the umbilical granuloma, development of rash, redness, pus, and discharge, around the umbilical granuloma, management of the umbilical granuloma by silver nitrate or stitching, using of Betadine for granuloma care, using of alcohol, using of cook salt over the stump to treat granuloma and presence of local signs of inflammation of the umbilical granuloma.

Scoring system for mothers' knowledge:

Correct answer was scored (1)

Wrong answer or don't know answer was scored (0)

The total score of Mothers' knowledge was calculated and classified as the following:

Less than $60 \%$ was considered poor knowledge.

$60-74 \%$ was considered fair knowledge.

$75<100 \%$ was considered good knowledge.

Tool II: Guideline reported educational intervention for the mothers: it includes 9 health instruction related to mothers' performance to care for their infants with granuloma; expose the center of the umbilicus, pressing gently on the skin around the umbilicus, complete expose the granuloma, soft paraffin jell to the surrounding skin, clean umbilicus area gently, observe umbilicus area for infection, apply a very small pinch of cook salt over the umbilical granuloma, cover the area with a clean piece of gauze, secure the salt in place for 30 minutes, after that time clean the site using gauze swab soaked with warm water.

Scoring system for Mothers' reported guideline practice was follows:

Done correctly and complete was score (1) Done incorrect or not done was score (0) The total scores of Mothers' reported practice was calculated and classified into two levels as follow:

60 to less than 74 will be considered unsatisfactory.

75-100 \% will be considered satisfactory.

\section{Method:}

- An official Permission was obtained from the responsible authorities.

- Ethical and legal consideration: a-Ethical committee approval was obtained

b- The study was not harmful or painful for the participants.

c- Privacy \& confidentiality was not violated throughout the study.

- The study tools were developed by researcher based on review of related literature to assess mothers' knowledge 
and performance of umbilical granuloma care and the use of cook salt.

- Tools of data collection were validity by three juries (two from Pediatric nursing of Tanta University, and one from faculty of Medicine at Menoufia University.

- A pilot study were performed on $10 \%$ of studied sample to test the tool for its clarity, applicability, feasibility and excluded from the study and the necessary modifications were done. The suitable statistical test was used for testing questionnaire reliability.

- Assessment tool for mothers' knowledge was filled in the outpatient clinic area (part 3). Mothers' reported practice observation checklist was filled out by the researcher to assess the actual mothers' practice before and after guideline intervention (Tool II). Study phases: the present study was established within four phases:

1-Assessment phase: It included assessment of mothers' knowledge and reported practice Tools I\& II

2-Preparatory phase: It involves reviewing the national and international related literature concerning the studied topic and gathering the tools of the study.

3-Implementation phase: it included the following steps: a. Setting objectives of the guideline.

b. Preparation of the content which covered the reasons behind the application of the session.

c. The teaching was conducted in two sessions. The time of each session was about 30-45 minutes or by a phone call.

d. Different methods and media of teaching were used including small lectures, discussion, demonstrations and pdf through watts-app.

- The first session include: definition of granuloma, time of development of granuloma after falling of umbilical stump, pain and irritation of the infant skin, development of rash, redness, pus, discharge, treatment by silver nitrate or stitching, using of Betadine to care for granuloma, using of alcohol as treatment of granuloma, usage of cook salt over the stump to treat granuloma and presence of signs of infection.

- The second session include: Focus on the infants with umbilical granuloma including expose the center of the umbilicus, pressing gently on the area around the umbilicus to complete expose the granuloma, soft paraffin jell to the healthy surrounding skin, clean umbilicus area gently, observe umbilicus area for infection, apply a 
very small pinch of cook salt over the umbilical granuloma, cover the area with a clean piece of gauze for 30 minutes, after that time clean the site using gauze swab soaked in warm water.

4-Evaluation phase: Evaluation of mother's knowledge and reported practice was done before and after guideline education using Tools I\& II.

- The data Collection was carried out from first day of January, 2018 to the last day of it, 2020. Statistical analysis: The data collected were organized, tabulated and statistically analyzed using statistical science (SPSS) version 21 for windows. Descriptive statistics were applied as frequency, percentages, means and standard deviation. Test of significance, Chisquare "X2", were used to test the study hypothesis.

- Reliability of the tools was done using Cronbach's Alpha. A significant level value was considered when $\mathrm{p}<0.05$ and a highly significant level value was considered

\section{Results:}

Table (1): Showed that the mean age of the studied infants group were 1.500 \pm .71611 , With predominance of male sex $65 \%$ more than three quarter $(77.5 \%)$. of them delivered by CS. Predominance of breast feeding in the studied group (75\%).
The mean duration of cord falling was $2.375 \pm 0.70483$ days while $92.55 \%$ showed excellence response to treatment.

Table (2): This table reported that nearly three quarter of mothers $(72.5 \%), 50 \%$, and $62.5 \%$ were age less than 30 years of age, primary school, not working and had two children only.

Table (3): This table demonstrates that mothers' total knowledge score about using common salt for treating granuloma before and after health education implementation training. The table proved that mothers' knowledge were improved significantly after the educational intervention with mean $\pm S D$ of $7.2 \pm 1.85$ and $11.9 \pm 4.07$ pre and post the intervention respectively

Table (4): Revealed that more than half $(52.5 \%)$ of mothers had poor level scores of total knowledge pre the educational intervention compared to most of them $77.5 \%$ after the educational intervention had good total knowledge score and there was significant improvement of the total mothers' knowledge level before and after the education with ( $p$ value $=0.001$ )

Table (5): Illustrate mothers' reported practice before educational program, it was observed that all $(100 \%)$ of them didn't exposure granuloma, cover area with a clean gauze, place 30 minutes and clean the site using a clean gauze soaked in warm water compared to post educational intervention where majority of them 
$(92.5 \%, \quad 97.5 \%, \quad 79.5 \%$ and $79.5 \%)$ respectively perform the steps. Difference between the two groups was highly significant correlation between before and after since $\mathrm{P}$ equal to .000. In addition; same table revealed that post health educational intervention majority of the studied mothers 95\%, 95\%, 95\%,97.5\% and $95 \%$ exposed center of umbilical ,apply paraffin jelly ,clean with warm water, observe umbilical area for infection and apply small pinch of salt respectively compared to pre the intervention $25 \%, 57.5 \%, 45 \%, 2.5 \%$ and $5 \%$.

Table (6): Revealed that three quarter $75 \%$ ) of mothers had poor scores of practice pre the educational guideline compared to post the educational intervention the majority of them $97.5 \%$ had good the total knowledge score and there were statistical significant difference between the total practice pre and post the educational intervention ( $\mathrm{p}$ value.003).

Table (7): It is evident from the table that there was a highly statistical significant correlation between mothers' age, and their total practice score pre the educational intervention where ( $\mathrm{P}$ value .000$)$ Also highly significant correlation was found between number of children and total mother knowledge and practice score post the educational intervention since $(\mathrm{P}$ value .000.) While there was no significant correlation was found between mothers of education post the educational intervention and their total knowledge and practice post educational intervention where $(\mathrm{p}$ value 0.350 ) and 0.134 respectively. 
Table (1): Percentage distribution of studied infants related to their biosocial data

\begin{tabular}{|c|c|c|}
\hline Biosocial data of studied infant & $\mathrm{N}=(\mathbf{4 0})$ & $\%$ \\
\hline $\begin{array}{l}\text { Infant age/weeks } \\
3>9 \\
9>12 \\
13 \geq 16\end{array}$ & $\begin{array}{l}25 \\
10 \\
5\end{array}$ & $\begin{array}{l}62.5 \\
25 \\
12.5\end{array}$ \\
\hline \multicolumn{3}{|c|}{ Mean \pm SD 1.5000 \pm .71611} \\
\hline $\begin{array}{l}\text { Sex: } \\
\text { Male } \\
\text { Female }\end{array}$ & $\begin{array}{l}30 \\
10\end{array}$ & $\begin{array}{l}75 \\
25\end{array}$ \\
\hline $\begin{array}{l}\text { Birth Weight: } \\
3<5 \mathrm{~kg} \\
\geq 5 \mathrm{~kg} \\
\text { More than5 }\end{array}$ & $\begin{array}{l}29 \\
11 \\
0\end{array}$ & $\begin{array}{l}72.5 \\
27.5 \\
0\end{array}$ \\
\hline $\begin{array}{l}\text { Type of delivery } \\
\text { Normal } \\
\text { Cesarean }\end{array}$ & $\begin{array}{l}9 \\
31\end{array}$ & $\begin{array}{l}22.5 \\
77.5\end{array}$ \\
\hline $\begin{array}{l}\text { Type of feeding: } \\
\text { Breast feeding } \\
\text { Artificial feeding } \\
\text { Mixed }\end{array}$ & $\begin{array}{l}30 \\
5 \\
5\end{array}$ & $\begin{array}{l}75 \\
12.5 \\
12.5\end{array}$ \\
\hline $\begin{array}{l}\text { Time the umbilical cord fall off/day } \\
\text { from } 7 \text { to } 8 \\
\text { from } 9 \text { to } 11 \\
\text { more than } 11\end{array}$ & $\mathrm{t}$ & $\begin{array}{l}12.5 \\
37.5 \\
50\end{array}$ \\
\hline Mean \pm SD of cord falling $2.375 \pm 0.7$ & & \\
\hline $\begin{array}{l}\text { Response of the treatment } \\
\text { good response } \\
\text { No response }\end{array}$ & $\begin{array}{l}37 \\
3\end{array}$ & $\begin{array}{l}92.5 \\
7.5\end{array}$ \\
\hline
\end{tabular}


Table (2): Percentage distribution of mothers related to their bio social demographiccharacteristics $(n=40)$

\begin{tabular}{|c|c|c|}
\hline Bio-social characteristics of studied mothers & $\begin{array}{c}\mathrm{N}=(40) \\
\text { No }\end{array}$ & $\%$ \\
\hline $\begin{array}{l}\text { age/year } \\
\begin{aligned}-\quad 20<30 \\
-\quad 30<40 \\
-\quad 40 \geq 50\end{aligned}\end{array}$ & $\begin{array}{c}29 \\
10 \\
1\end{array}$ & $\begin{array}{l}72.5 \\
25 \\
2.5\end{array}$ \\
\hline Mean \pm & & \\
\hline $\begin{array}{l}\text { Educational Level: } \\
\begin{aligned}- & \text { Illiterate } \\
- & \text { Primary school } \\
- & \text { Secondary education school } \\
- & \text { University education }\end{aligned}\end{array}$ & $\begin{array}{c}4 \\
20 \\
8 \\
8\end{array}$ & $\begin{array}{l}10 \\
50 \\
20 \\
20\end{array}$ \\
\hline $\begin{array}{l}\text { Occupation: } \\
\text { Not working } \\
\text { Working }\end{array}$ & $\begin{array}{l}29 \\
11\end{array}$ & $\begin{array}{l}72.5 \\
27.5\end{array}$ \\
\hline $\begin{array}{l}\text { Number of children in the family:- } \\
1 \\
2 \\
3 \\
5 \text { and more }\end{array}$ & $\begin{array}{c}7 \\
25 \\
6 \\
2\end{array}$ & $\begin{array}{c}17.5 \\
62.5 \\
15 \\
5\end{array}$ \\
\hline
\end{tabular}


Table (3): Mother's Knowledge about using salt to treat granuloma before and after implementation of health education

\begin{tabular}{|c|c|c|c|c|c|c|c|c|c|c|}
\hline \multirow{3}{*}{$\begin{array}{l}\text { Mothers knowledge about } \\
\text { granuloma }\end{array}$} & \multicolumn{4}{|c|}{$\begin{array}{l}\text { Pre health education } \\
\qquad \mathrm{N}=(40)\end{array}$} & \multicolumn{4}{|c|}{$\begin{array}{l}\text { After health education } \\
\qquad \mathbf{N}=\mathbf{( 4 0 )}\end{array}$} & \multirow{3}{*}{$X^{2}$} & \multirow{3}{*}{$\mathbf{P}$} \\
\hline & \multicolumn{2}{|c|}{ True } & \multicolumn{2}{|c|}{ False } & \multicolumn{2}{|c|}{ True } & \multicolumn{2}{|c|}{ False } & & \\
\hline & No & $\%$ & No & $\%$ & No & $\%$ & No & $\%$ & & \\
\hline \multicolumn{11}{|l|}{ Granuloma } \\
\hline - $\quad$ Definition & $20^{*}$ & $50 *$ & 20 & 50 & $36^{*}$ & $90 *$ & 4 & 10 & $.333^{*}$ & .036 \\
\hline - Time of formation & $30^{*}$ & $75^{*}$ & 10 & 25 & $35^{*}$ & $85.5^{*}$ & 5 & 12.5 & .480 & .002 \\
\hline $\begin{array}{ll}- & \text { Cause of } \\
\text { granulation pain }\end{array}$ & 32 & 80 & $8^{*}$ & $20 *$ & 10 & 25 & $30 *$ & $75^{*}$ & $-.380-{ }^{-\prime}$ & .016 \\
\hline $\begin{array}{l}\text { Causes of rash, } \\
\text { Redness and pus } \\
\text { fluid }\end{array}$ & $30 *$ & $75^{*}$ & 10 & 25 & $36^{*}$ & $90 *$ & 4 & 10 & $.577^{*}$ & .000 \\
\hline
\end{tabular}

\section{Treatment of granuloma}

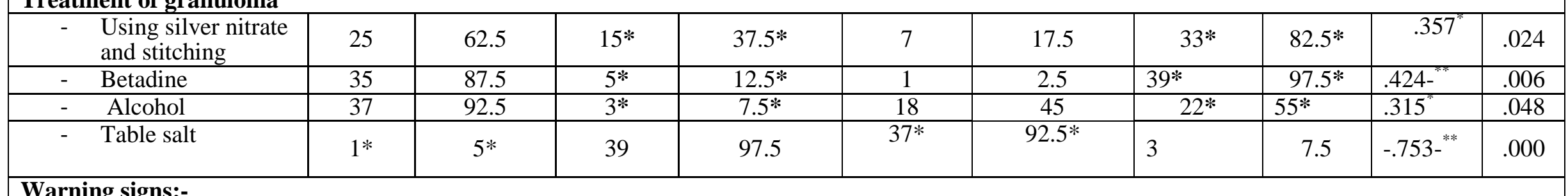

\section{Warning signs:-}

\begin{tabular}{|c|c|c|c|c|c|c|c|c|c|c|c|}
\hline- & Edema & $35 *$ & $87.5 *$ & 5 & 12.5 & $39 *$ & $97.5^{*}$ & 1 & 2.5 & $.424^{\text {*N* }}$ & .006 \\
\hline- & Fever & $36^{*}$ & $90 *$ & 4 & 10 & $36 *$ & $90 *$ & 4 & 10 & .306 & .055 \\
\hline- & Redness & $38 *$ & $95 *$ & 2 & 5 & $36 *$ & $90 *$ & 4 & 10 & $.688^{\pi}$ & .000 \\
\hline- & Pus & $38 *$ & $95 *$ & 2 & 5 & $35^{*}$ & $87.5^{*}$ & 5 & 12.5 & $.607^{* *}$ & .000 \\
\hline- & Pain & 38 & 95 & $2 *$ & $5 *$ & 3 & 7.5 & $37 *$ & $92.5 *$ & .286 & .074 \\
\hline- & Continuous cry & 38 & 95 & $2 *$ & $5 *$ & 11 & 27.5 & $29 *$ & $72.5 *$ & $-.032-$ & .843 \\
\hline \multirow{2}{*}{\multicolumn{2}{|c|}{$\begin{array}{l}\text { Total knowledge } \\
(\text { mean } \pm \text { SD) }\end{array}$}} & \multicolumn{4}{|c|}{$\%($ mean \pm SD $)$ Pre } & \multicolumn{4}{|c|}{$\%($ mean \pm SD) Post } & T Paired & Sig \\
\hline & & \multicolumn{4}{|c|}{$7.2 \pm 1.85$} & \multicolumn{4}{|c|}{$11.9 \pm 4.07$} & $489^{* *}$ & .001 \\
\hline
\end{tabular}

$*=$ Correct response

$*$ Statistical significant difference $(\mathbf{p}<\mathbf{0 . 0 5})$

$* *$ A highly statistical significant difference $(P \leq 0$.001) 
Table (4): Distribution of the studied Mothers according to their total knowledge level about using of salt to treat granuloma pre and post educational intervention $(n=40)$

\begin{tabular}{|c|c|c|c|c|c|c|}
\hline \multirow[t]{2}{*}{ Total Knowledge } & \multicolumn{2}{|c|}{$\begin{array}{c}\text { Pre Program } \\
\text { Education } \\
(\mathbf{4 0})\end{array}$} & \multicolumn{2}{|c|}{$\begin{array}{c}\text { After one month } \\
\text { of Program } \\
\text { Education } \\
(40)\end{array}$} & \multirow[t]{2}{*}{$\mathbf{X} 2$} & \multirow{2}{*}{$\begin{array}{c}\text { P- } \\
\text { value }\end{array}$} \\
\hline & No & $\%$ & No & $\%$ & & \\
\hline Good & 1 & 2.5 & 31 & 77.5 & \multirow{3}{*}{$489^{* *}$} & \multirow{3}{*}{.001} \\
\hline Average & 18 & 45 & 4 & 10 & & \\
\hline Poor & 21 & 52.5 & 5 & 12.5 & & \\
\hline
\end{tabular}

**. Correlation is significant at the 0.01 level (2-tailed).

Table (5): Mothers' reported Practice regarding using of salt to treat granuloma before and after educational intervention

\begin{tabular}{|c|c|c|c|c|c|c|c|c|c|c|}
\hline \multirow{2}{*}{ Mothers practice } & \multicolumn{4}{|c|}{ Pre Health Education (40) } & \multicolumn{4}{|c|}{ (40) After health Education } & \multirow{2}{*}{$\mathbf{T}$} & \multirow{2}{*}{$\mathbf{P}$} \\
\hline & \multicolumn{2}{|c|}{ Done } & \multicolumn{2}{|c|}{ Not done } & \multicolumn{2}{|c|}{ Done } & \multicolumn{2}{|c|}{ Not done } & & \\
\hline 1. Expose the center of the umbilicus. & 10 & 25 & 30 & 75 & 38 & 95 & 2 & 5 & .415 & .132 \\
\hline $\begin{array}{l}\text { 2.Pressing gently on the area around the } \\
\text { umbilicus }\end{array}$ & $\mathbf{0}$ & $\mathbf{0}$ & 40 & 100 & 37 & 92.5 & 3 & 7.5 & $.806^{* *}$ & .000 \\
\hline $\begin{array}{l}\text { 3.Apply soft paraffin jelly to surrounding } \\
\text { skin }\end{array}$ & 23 & 57.5 & 17 & 42.5 & 38 & 95 & 2 & 5 & .267 & .096 \\
\hline $\begin{array}{l}\text { 4.Clean umbilicus area gently with warm } \\
\text { water }\end{array}$ & 18 & 45 & 22 & 55 & 38 & 95 & 2 & 5 & .208 & .199 \\
\hline $\begin{array}{l}\text { 6.Apply table salt over the umbilical } \\
\text { granuloma }\end{array}$ & 2 & 5 & 38 & 95 & 38 & 95 & 2 & 5 & .306 & .05 \\
\hline 7.Cover the area with a clean piece of gauze a & $\mathbf{0}$ & $\mathbf{0}$ & 40 & 100 & 39 & 97.5 & 1 & 2.5 & $.806^{* * *}$ & .000 \\
\hline 8. Secure the salt in place for 30 minutes & $\mathbf{0}$ & $\mathbf{0}$ & 40 & 100 & 39 & 97.5 & 1 & 2.5 & $.806^{* *}$ & .000 \\
\hline $\begin{array}{l}\text { 9.Clean the site using a clean gauze swab } \\
\text { soaked in warm water }\end{array}$ & $\mathbf{0}$ & 0 & 40 & 100 & 39 & 97.2 & 1 & 2.5 & $.806^{* *}$ & .000 \\
\hline
\end{tabular}

Vol. 22 No. 3 (Suppl), August 2021 
Table (6) :Distribution of the studied mothers regarding their total practice level about using salt in the treatment of granuloma pre and post education $(n=40)$

\begin{tabular}{||c|c|c|c|c|c|c||}
\hline \multirow{2}{*}{$\begin{array}{c}\text { Total practice of } \\
\text { mother }\end{array}$} & \multicolumn{2}{|c|}{$\begin{array}{c}\text { Before health } \\
(\mathbf{n = 4 0})\end{array}$} & \multicolumn{2}{|c|}{$\begin{array}{c}\text { After health } \\
\text { Education } \\
(\mathbf{n = 4 0})\end{array}$} & \multirow{2}{*}{$\mathbf{t}$} & \multirow{2}{*}{ Sig } \\
\cline { 2 - 5 } & No & $\mathbf{\%}$ & No & \% & \\
\hline Good & 0 & $0 \%$ & 39 & 97.5 & \multirow{2}{*}{$.454^{* *}$} & \multirow{2}{*}{.003} \\
\hline Average & 10 & 25 & 1 & 2.5 & & \\
\hline Poor & 30 & 75 & 0 & $0 \%$ & & \\
\hline
\end{tabular}

**. Correlation is significant at the 0.01 level (2-tailed).

Table (7): Correlation between bio-socio characteristics and mothers' knowledge, practice pre and post the educational intervention

\begin{tabular}{|l|c|c|c|c|c|c|c|c|}
\hline \multirow{2}{*}{ Variable } & \multicolumn{2}{|c|}{ Mother' age } & \multicolumn{2}{c|}{ Number of children } & \multicolumn{2}{c|}{ Occupation } & \multicolumn{2}{c|}{$\begin{array}{l}\text { Level of } \\
\text { education }\end{array}$} \\
\cline { 2 - 9 } & $\mathbf{R}$ & $\begin{array}{c}\text { p- } \\
\text { value }\end{array}$ & $\mathbf{R}$ & p-value & $\mathbf{R}$ & $\begin{array}{c}\text { p- } \\
\text { value }\end{array}$ & R & $\begin{array}{c}\text { p- } \\
\text { value }\end{array}$ \\
\hline $\begin{array}{l}\text { Total knowledge } \\
\text { pre }\end{array}$ & .135 & .230 & .038 & $.329^{*}$ & .022 & $.360^{*}$ & .040 & $-.325^{*}$ \\
$\begin{array}{l}\text { Total practice } \\
\text { pre }\end{array}$ & .000 & $.776^{*}$ & .000 & $.674^{* *}$ & .586 & .089 & .253 & .185 \\
\hline $\begin{array}{l}\text { Total knowledge } \\
\text { post }\end{array}$ & .001 & $.516^{*}$ & .000 & $.751^{* *}$ & .026 & $.352^{*}$ & .350 & .125 \\
$\begin{array}{l}\text { Total practice } \\
\text { post }\end{array}$ & .104 & .261 & .000 & $.596^{* *}$ & .088 & .273 & .134 & .240 \\
\hline
\end{tabular}

**. Correlation is significant at the 0.01 level (2-

tailed). 


\section{Discussion}

An umbilical granuloma shapes like a small piece of bright red, moist flesh that still in the umbilicus after cord separation when normal healing should have occurred Child Health Information (2015) ${ }^{(11)}$. Despite the spontaneous regression of the untreated granuloma is not well documented, some authors recommend clinical follow-up (dry care) without any medication or intervention Hossain et al., $(2015)^{(11)}$,Lotain et al ., (2002) $)^{(14)}$ and Whistion Hospital Children $(2018)^{(10)}$. In this study pre health education the mothers did not have any knowledge about using salt for umbilical granuloma treatment but after health education the mothers had good knowledge. It was agreed with Haftu H, (2020) (16) who found after mothers were counseled on details how to apply the cooking salt and appointed for the subsequent follow-ups for assessment of the outcome, any adverse effect, and recurrences.

In this study, topical salt had a high response rate without recurrence. The curative mechanism of salt on granuloma is through its desiccant effect and other biologic properties; the high concentration of sodium ion in the area draws water out of the cells and results in shrinkage and necrosis of the wet granulation tissue. These properties are speculated to be part of the therapeutic mechanisms involved in our study. However, this effect is not so powerful as to cause damage to normal surrounding keratinized skin when applied for short duration. Sunshi et al.,(2018) ${ }^{(8)}$ it was in accordance with a study conducted by Hossain., et al. ${ }^{(18)}$ and Saleh .A(2016) (19) showed excellent response to the common salt over umbilical granuloma with no adverse effects. Salt therapy is associated with minor complications and less recovery time and total costs, compared with silver nitrate. The umbilical granuloma treated with common salt usually clears within 4 - days to weeks. Sunshi et al.,(2018) ${ }^{(18)}$.

In this study after health education mothers had good practice response to use salt and the use of salt to treat granuloma easy to use and complete regression with no/reversible mild side effects of salt treatment are few in number. Assi (2020) ${ }^{(19)}$,Lotan $(2002)^{(14)}$, Halftu $(2020)^{(20)}$ and Faranoush et al. (2006) ${ }^{(21)}$.demonstrated a $100 \%$ cure rate of salt treatment with no adverse effect and no recurrence in the subsequent follow-up of the infants. Studies done by Halftu $(2020)^{(14)}$ show excellent response in $91.7 \%$ of infants with a clinical diagnosis of umbilical granuloma and treated with cooking salt Fahat $(2008)^{(18)}$, Bagadia et al. (2019) $)^{(19)}$, Nathan $(2020)^{(25)}$ and Salah (2016) ${ }^{(10)}$. There were no reported side effects and no recurrence. 
These infants were treated with surgery and the polyps were excised. Hossain et al (2012) (13). This shows that the misdiagnosis of polyps for granuloma lowers the cure rate of salt treatment. We can conclude that the response rate in this study was higher than $91.7 \%$ if a corrected diagnosis of the umbilical granuloma was made. Fahat $(2008)^{(21)}$ who found infant's in the salt group showed an excellent response rate $(95 \%)$ than silver nitrate $(87.6 \%)$ and they had no reported side effects and recurrence rates. But in silver nitrate groups, $19 \%$ of them had complications, and 9\% of them had a recurrence of the umbilical granuloma and infants were unresponsive to common salt and silver nitrate for the treatment due to misdiagnosis of granuloma for polyp Dhungel et al. (2018) ${ }^{(21)}$.

Also. Badebrarin $(2018)^{(22)}$ did a clinical trial of infants with umbilical granuloma comparing the response rate of children who were treated with salt and surgical excision, which showed a $95 \%$ response rate after they were treated for five days and the unresponsive patients were treated for five additional days with salt and showed complete recovery except one who was misdiagnosed as a granuloma for a polyp and was treated surgically. Badebrarin (2018) ${ }^{(22)}$ so the response rate of salt in this study was almost $100 \%$ over the duration of treatment. This study showed an extension of treatment duration gained an additional response rate.

\section{Conclusion}

Mothers had poor knowledge and practice about use salt to treat infant with umbilical granuloma pre educational intervention guideline which has been increased post the educational intervention and application of common salt (table/ cooking salt) to the umbilical granuloma is a simple highly effective and non-expensive form of treatment of umbilical granuloma with no any relapse or complications. Treatment can be performed by doctors, nurses, primary health care staffs and even by parents.

\section{Recommendation}

Increase awareness of health staff to teach mothers about using of cooking salt for the management of umbilical granuloma because it improve its effectiveness, cheap, available, and easy to apply by health and non-health professionals.

\section{Reference}

1. Hossain A. Hasan G. Islam K.Therapeutic effect of common salt (Table/ Cooking Salt) on Umbilical Granuloma in infants. Bangladesh J. Child Health. 2010; 34 (3): 99-102.

2. Gras-Le Guen C, Caille A, Launay E, Boscher C, Godon N, Savagner C, et al. Dry care versus antiseptics for umbilical cord care: A cluster 
randomized trial. Pediatrics. 2017;139(1):1-5

3. Brady M, Conway B, Zaenglein L, Helm F. Umbilical Granuloma in a 2month-old patient: Histopathology of a Common Clinical Entity. Am. J. Dermatopathol. 2016; 38(2):133-4.

4. Ali MA, Thrower SL, Hanna SJ, Coulman SA, Birchall JC, Wong FS, et al. Topical steroid therapy induces pro-tolerogenic changes in Langerhans cells in human skin. Immunology. 2015;146(3):411-22.

5. Brunner $M$, Khattri $S$, Garcet $S$, Finney R, Oliva M, Dutt R, et al. A mild topical steroid leads to progressive anti-inflammatory effects in the skin of patients with moderateto-severe atopic dermatitis. J Allergy Clin Immunol. 2016;138(1):169-78.

6. Tempark $\mathrm{T}$, Phatarakijnirund $\mathrm{V}$, Chatproedprai S, Watcharasindhu S, Supornsilchai V, Wananukul S. Exogenous Cushing's syndrome due to topical corticosteroid application: Case report and review literature. Endocrine. 2010; 38(3): 328-34.

7. Yamamoto A, Sakamoto Y. Examination of treatments for umbilical granuloma-efficacy of topical steroid treatment. Journal of Japan Society of Perinatal and Neonatal Medicine. 2011; 47(2): 347.
8. Amrit Pokhrel2 and Anshu Acharya et al. Outcomes and cost analysis of salt therapy versus Silver Nitrate for treatment of Umbilical Granuloma: 4years' experience in a Private Health Centre. EC Paediatrics. 2018; 653659.

9. Fiaz M, Bhatti BA, Ahmed N, et al. A comparative study of the therapeutic effects of copper sulfate versus common salt (sodium chloride) in the treatment of infantile umbilical granuloma. Jmscr. 2017; 5(11):3112731132. Doi:10.18535/jmscr/v5i11.226

10. Abdullah S. Therapeutic effect of common salt on umbilical granuloma in infants. International Journal of Medical Science and Public Health. 2016;3(22) 911-914.

11. Child Health Information. Umbilical granuloma in babies, royal united hospitals bath NHS. Foundation Trust. 2015; 1-2.

12. Hossain AZ, Hasan GZ, Islam KD. Therapeutic effect of common salt (table/cooking salt) on umbilical granuloma in infants. Bangladesh $\mathbf{J}$ Child Health. 2012; 34(3): 99-102. Doi:10.3329/bjch.v34i3.10360

13. Whiston Hospital Children's Community Nursing Team. Salt treatment for umbilical granuloma in babies, St Helens, and Knowsley a 
teaching hospital. Peadiatr Health Med Therap. 2018.5(13):233-234

14. Haftu H, Bitew H, Gebrekidan A, Gebrearegay $\mathrm{H}$.The outcome of salt treatment for Umbilical Granuloma: A systematic review. $2020 ; 14(10)$ : $2085-2092$.

15. Assi NA, Kadem KM, Alrubaee JR.Management of umbilical granuloma. Thi-Qar Med J. 2010; 4(4): 82-87.

16. Haftu H, Gebrehiwot T, Gidey A. Salt treatment for umbilical granuloma: Effective, cheap and available alternative option of treatment. Case Rep Pediatr Health Med Therap. 2020; 11(1): $\quad 393-397 . \quad$ Doi: 10.2147/PHMT.S269114.

17. Faranoush M, Gohorbani R, Malek M, et al. Comparative study on therapeutic effect of sodium chloride and alcohol in infants with umbilical granuloma. J Kazvin Univ MED. 2006; 10(2): 65-68.

18. Farhat A, Mohammadzadeh A. Comparison between two and twentyfour hours salt powder in treatment of infant umbilical granuloma. IRCMJ. 2008; 10(4): 267-269.

19. Bagadia J, Jaiswal $S$, Bhalala KB, et al. Pinch of salt: A modified technique to treat umbilical granuloma. Natl Inst Health. 2019; 36(4): 561-563.
20. Nathan TA. The umbilicus, granuloma. Nelson Pediatr. 2020; 5(12) :4175-4176.

21. Dhungel S, Pokhrel A, Acharya A. Outcomes and cost analysis of salt therapy versus silver nitrate for treatment of umbilical granuloma: 4years' experience in a private health centre; 4-years' experience in a private health centre. EC Pediatr. 2018;7(7):653-659.

22. Badebrarin D, Jamshidi M, Aabadi $\mathrm{SA}$, et al. A comparison between the clinical results of salt therapy and surgery in the treatment of umbilical granuloma in infants. Iran $\mathrm{J}$ Pediatr Surg. 2018; 4(1): 1-13. 